GRAŻYNA TEUSZ

Uniwersytet im. Adama Mickiewicza

$w$ Poznaniu

\title{
PRZEZ TY CZŁOWIEK STAJE SIĘ JA. COACHING I FILOZOFIA DIALOGU - KONSTRUKTYWNE SPOTKANIE
}

\begin{abstract}
Teusz Grażyna, Przez Ty człowiek staje się Ja. Coaching i filozofia dialogu - konstruktywne spotkanie [Through You the Human Person Becomes I. Coaching and the Philosophy of Dialog a Constructive Encounter]. Studia Edukacyjne nr 43, 2017, Poznań 2017, pp. 193-204. Adam Mickiewicz University Press. ISSN 1233-6688. DOI: 10.14746/se.2017.43.12

The article discusses selected aspects of the philosophy of dialog, and then makes relations between them and the theory and practice of coaching. The platform which significantly bridges the two approaches is the perspective of encounter and the dialogical relation, which come into play in the interpersonal I and You relation (coach - client) and the resultant experience, conditions and consequences. Empathy is one of the possible efficient tools of dialog. It is a criterion for a genuine encounter that is one of the assumptions of the philosophy dialog.
\end{abstract}

Key words: dialogue, dialogue philosophy, coaching, empathy, communication

\section{Czym jest coaching?}

Wokół terminu „coaching” narosło wiele semantycznie nieostrych i niejednoznacznych interpretacji.

Zadziwiający sukces coachingu do pewnego stopnia wskazuje na charakterystyczny przejaw mody pojęciowej, a nawet można mówić o pewnym nadużyciu semantycznym. Okazuje się, że w praktyce życia codziennego, w piśmiennictwie popularyzatorskim, ale czasami też fachowym, stosuje się określenia, sprawiające wrażenie, że prawie wszystko można nazwać coachingiem ${ }^{1}$.

${ }^{1} \mathrm{~J}$. Surzykiewicz, Podstawy teoretyczne coachingu w pedagogice społecznej i pracy socjalnej: $k u$ coachingowi społecznemu, [w:] Coaching społeczny. W poszukiwaniu efektywnych form wsparcia osób w trudnych sytuacjach życiowych, red. J. Surzykiewicz, M. Kulesza, Warszawa 2013, s. 21. 
Określając nim zatem zwyczajowo najczęściej wszystko, co wiąże się $\mathrm{z}$ rozwojem osobistym, sytuuje się go $\mathrm{w}$ przestrzeni szeroko rozumianych oddziaływań wspierających osobę, których celem jest skłonienie jej do zatrzymania się $\mathrm{w}$ biegu życia oraz spokojnej refleksji, zastanowienia i odkrycia tego, co z wykorzystaniem w stopniu maksymalnym własnych zasobów, zdolności i wiedzy jest możliwe do wprowadzenia w życie jako $\mathrm{w}$ danej sytuacji najlepsze rozwiązanie. Inaczej rzecz ujmując, można by powiedzieć, że istotę coachingu stanowi samorozwój, próba znalezienia przez jednostkę odpowiedzi na pytania: kim jestem? czego tak naprawdę chcę i pragnę? co, biorąc pod uwagę mój osobowy potencjał, mogę oraz potrafię zmienić i osiągnąć, a co jest poza moimi możliwościami? Wnikliwa analiza, spokojny i dojrzały namysł oraz wgląd w siebie powinny prowadzić ku konkretnym postanowieniom, decyzjom i rozstrzygnięciom. Można by powiedzieć, że podejmowana w coachingu refleksja, której rezultatem jest sui generis poszerzenie świadomości, uświadomienie sobie wyzwań, celów i wartości oraz własnych kompetencji i potencjału, projektuje niejako swoiste ramy dla samorozwoju.

W otwierającym książkę Coaching. Inspiracje z perspektywy nauki, praktyki $i$ klientów rozdziale, zatytułowanym Coaching $z$ wielu perspektyw przywołano kilka definicji coachingu, umożliwiających wgląd $\mathrm{w}$ jego istotę oraz $\mathrm{w}$ postrzeganie go przez praktyków, jak i klientów ${ }^{2}$. Po ich zaprezentowaniu, w części - Coaching oparty na dowodach, redaktor pracy Paweł Smółka, konstatuje:

odpowiedź na pytanie, czym jest coaching, wbrew pozorom, nie jest wcale łatwa. Wiele definicji coachingu jest tak ogólnych, abstrakcyjnych i mało precyzyjnych, że nie dziwi fakt, iż pod etykietą "coaching” można znaleźć lub zawrzeć w zasadzie wszelkiego rodzaju praktyki związane ze wspieraniem, doskonaleniem, a nawet leczeniem (psychoterapią) ludzi³.

Następnie, wskazując, iż definicyjne próby nie „budują unikalnej tożsamości coachingu" i nie eksplikują tego, co wyróżnia go spośród wielu innych form wspierania rozwoju, a tym samym, „nie pozwalają na jego (...) profesjonalizację, jako samodzielnego obszaru praktyki" ${ }^{4}$ prezentuje kilka przykładów swego rodzaju metamodelu coachingu, jako koncepcyjnej ramy, „która - jak zauważa - wyróżnia zasadnicze, wspólne cechy coachingu nie-

${ }^{2}$ Coaching. Inspiracje z perspektywy nauki, praktyki i klientów, red. P. Smółka, Gliwice 2009, s. $8-20$.

3 Tamże, s. 26.

4 Tamże. Zob. także: Część 2 - Modele i techniki coachingu, [w:] Coaching doskonaty, s. 119-232. 
zależnie od konkretnego podejścia" 5 . Pierwszym jest, zaproponowany przez Stobera i Granta, „model kontekstualny”. Wśród istotnościowych elementów odnajdywanych $\mathrm{w}$ każdym procesie coachingowym, które zawarte są we wspomnianym modelu, znajdują się: relacja klient - coach, cel współpracy $\mathrm{w}$ ramach relacji klient - coach, procedura/plan wspierania klienta $\mathrm{w}$ realizacji wybranego przez niego wspólnie z coachem celu ${ }^{6}$.

Innym przykładem metamodelu coachingu, który przywołuje, jest model „osobistej konsultacji” Popovica i Boniwella, w którym zostają wyróżnione dwa zasadnicze elementy: relacja klient - coach oraz proces zmiany. Dynamiczna relacja klient - coach realizuje się w trzech wymiarach: 1) bycie $\mathrm{z}$ klientem lub działanie $\mathrm{z}$ klientem, 2) koncentracja na istniejących wzorcach zachowania, myślenia i przeżywania lub koncentracja na pożądanych wzorcach zachowań, myślenia i przeżywania, 3) koncentracja na kwestiach intrapsychicznych lub koncentracja na kwestiach interpersonalnych lub związanych $\mathrm{z}$ otoczeniem klienta. Wyróżnione elementy stanowiłyby swego rodzaju „miejsca wspólne” różnorodnych oddziaływań, praktyk coachingu. Jak zauważa Smółka:

modele coachingu dostarczają ram dla jego praktyki, jednakże ostateczny kształt relacji klient - coach oraz sposobu wspierania klienta przez coacha jest wyznaczony potrzebami i oczekiwaniami klienta, a nie sztywnymi wytycznymi jakiegokolwiek modelu ${ }^{7}$. Niezależnie od podejścia teoretycznego coacha - kontynuuje - oraz formatu prowadzonych przez niego sesji coachingu praktyka zawsze obejmuje następujące elementy: nawiązanie kontaktu i rozwój relacji klient - coach, pomoc klientowi w przemyśleniu i ustaleniu celu współpracy oraz zaangażowanie klienta w działania na rzecz realizacji wybranych przez niego celów ${ }^{8}$.

Jednym z kluczowych, by nie powiedzieć konstytutywnych składników coachingu jest relacja coach - klient, fundowany na niej kontakt, jego jakość. Owa jakość kontaktu wyznaczona jest przez oparcie go na równości, zaufaniu, partnerstwie, wzajemnym rozumieniu i współpracy. Tylko w tak zakreślonych ramach może przebiegać stymulowanie klienta do autorefleksji, do wzrostu samoświadomości wykraczającej poza powierzchowną eksplorację własnej, bieżącej sytuacji oraz analizę aktualnych możliwości9. Dla coacha zaś relacja z klientem stanowi sposobność, swoiste wyzwanie do podjęcia refleksji nad własną praktyką tak, aby przyswojoną wiedzę twórczo wyko-

\footnotetext{
5 Tamże, s. 29.

${ }^{6}$ Tamże, s. 29-30.

7 Tamże, 32.

8 Tamże, s. 36.

9 Tamże, s. 38.
} 
rzystać i zabezpieczyć tym samym profesjonalną praktykę coachingu, aby wypracować realistyczny wgląd „w sposób nawiązywania kontaktu i podtrzymywania relacji z klientem, a także rozumienia jego świata"10.

Coaching jest szczególną, międzyosobową relacją, która swoją najpełniejszą reprezentację uzyskuje $\mathrm{w}$ rozmowie, $\mathrm{w}$ dialogu. Zaistniałe $\mathrm{w}$ relacji coachingowej spotkanie Ja - Ty przybiera zatem postać dialogową. We Wprowadzeniu do książki Coaching jako konstruktywny dialog, będącej obszernym, kompleksowym omówieniem kwestii dialogu w coachingu, czytamy:

Dialog jest sercem każdej istotnej relacji coachingowej, a zarazem koniecznym warunkiem rozwoju indywidualnego i społecznego - to właśnie dzięki niemu można mówić o prawdziwym spotkaniu dwóch osób. Bez takiego spotkania, bez możliwości przejrzenia się w oczach innego podmiotu, bez nazwania i wyrażenia własnych myśli, bez empatycznego otwarcia się i usłyszenia myśli drugiego człowieka oraz bez wymiany poglądów prowadzącej do współtworzenia nowych idei - niemożliwe byłoby ani samopoznanie, ani tworzenie więzi, ani też indywidualny czy społeczny progres. (...) W tym kontekście coaching, rozumiany jako konstruktywny dialog, staje się nie tylko sposobem na zaspokojenie jednej z fundamentalnych ludzkich potrzeb, ale także pięknym i skutecznym narzędziem służącym do facylitacji indywidualnego i społecznego rozwoju ${ }^{11}$.

Aleksandra Szewczyk ujmuje rozumienie i pojmowanie postawy dialogu w coachingu jako sui generis aktywność artystyczną:

...prowadzenie konstruktywnego dialogu w coachingu jest sztuką, którą należy zgłębić i stosować, korzystając z narządzi odpowiednio dobranych do sytuacji, osoby poddającej się procesowi coachingu i do kontekstu - niczym malowanie obrazu wybranymi technikami na płótnie. Dialog prowadzony między dwojgiem ludzi można by nazwać rzemiosłem, a dialog prowadzony w coachingu sztuką, bo potrzebne są (...) narzędzia oraz odpowiednio przeszkolona i przygotowana do tego osoba, która rzemiosło zamieni w sztukę ${ }^{12}$.

\section{Perspektywa filozofii dialogu}

Zaprezentowane punkty widzenia, zarysowujące perspektywę szczególnej otwartości podmiotowej, osobowej relacji coachingowej, skierowują naszą uwagę na nurt myślenia wyznaczony przez filozofię dialogu. Nie sposób

10 Tamże, s. 45.

${ }^{11}$ L.D. Czarkowska, Coaching jako konstruktywny dialog. Wprowadzenie, [w:] Coaching jako konstruktywny dialog, red. L.D. Czarkowska, Warszawa 2016, s. 12.

12 A. Szewczyk, Sztuka prowadzenia dialogu w coachingu, [w:] Coaching jako konstruktywny dialog, s. 82 . 
w tym miejscu dokonać szczegółowej charakterystyki - założeń kierunku oraz poglądów jego głównych przedstawicieli. Istnieje obszerna, bogata literatura przedmiotu odnosząca się do tego nurtu filozoficznego określanego niekiedy także filozofią spotkania ${ }^{13}$. Intencją moją jest jedynie wskazanie kilku „newralgicznych” punktów stycznych, uwypuklenie niektórych „miejsc wspólnych”, ukazanie ożywczej inspiracji formułowanych na gruncie filozofii dialogu twierdzeń dla coachingu ${ }^{14}$.

Punktem wyjścia, który w zasadniczy sposób zbliża do siebie coaching i filozofię dialogu jest kategoria spotkania, ponieważ spotkanie jest warunkiem sine qua non zaistnienia samej sytuacji dialogu. W spotkaniu zaś chodzi o wzajemne poznanie, które dokonuje się według scenariusza swoistej, do niczego nieredukowalnej, osobowej intencjonalności. Spotkanie to także relacja. „Podstawowe słowo Ja - Ty ustanawia świat relacji” czytamy u Martina Bubera ${ }^{15}$. Filozofowie dialogu dla ukazania wartości spotkania, które charakteryzować się powinno bezpośredniością doświadczenia i otwartością, posługiwali się metaforą twarzy. Prawda o drugim, jego inność, odmienność miałaby się zawierać i być komunikowana, jak to ujmował Emmanuel Levinas, w epifanijności twarzy. Doświadczenie drugiego, jego naoczności i bezpośredniości, następuje poprzez bycie $\mathrm{z}$ nim twarzą w twarz. „Twarz jest sensem ze względu na nią samą"16, a „inny poprzez swoją twarz obecny jest nie $\mathrm{w}$ horyzoncie poznania, lecz etycznego wezwania”17. „Twarz jest etyczną prośbą, która zawiera w sobie jednocześnie zakaz i nakaz etyczny. Stawia opór i jednocześnie wzywa do odpowiedzialności"18. Odpowiedzialność, w rozumieniu Levinasa, jest najważniejszym, pierwotnym elementem składowym każdej międzyosobowej relacji, na którym fundują się, w sposób świadomy i wolny, tworzone więzi. „Zanim bowiem wejdziemy $\mathrm{w}$ jakiekolwiek relacje, jesteśmy odpowiedzialni za innych" 19 .

13 Zob. T. Gadacz, Filozofia dialogu, w: tenże, Historia filozofii XX wieku, t. 2 - Neokantyzm, filozofia egzystencji, filozofia dialogu, Kraków 2009, s. 501-638 (tu także bogata bibliografia, s. 656662).

14 Zagadnienie to pojawia się jako płaszczyzna ilustracyjna i porównawcza $\mathrm{w}$ tekstach zgromadzonych we wspomnianej już książce Coaching jako konstruktywny dialog. Chciałabym jednakże wyeksplikować kilka jeszcze płaszczyzn wzajemnego odniesienia obu rzeczywistości, które w pewnym sensie mogłyby dopełnić zaprezentowany obraz.

${ }_{15}^{15}$ M. Buber, Ja i Ty. Wybór pism filozoficznych, przekł. J. Doktór, Warszawa 1992, s. 41.

${ }^{16}$ E. Levinas, Etyka i Nieskończony. Rozmowy z Philipp'em Nemo, przekł. B. OpolskaKokoszka, Kraków 1991, s. 50.

17 T. Gadacz, Filozofia dialogu, s. 593.

18 Tamże.

19 Tamże, s. 594. 
Dlaczego ten etyczny wymiar jest tak ważny? Głównie z tego względu, że jego brak, usunięcie, naraża relację $\mathrm{z}$ drugim na proces dominacji, wyzwala pragnienie osiągnięcia nad nim władzy, panowania. Twarz stanowi zatem niejako swego rodzaju „wartość”, która zatrzymuje, nie pozwala na zawładnięcie drugim. Twarz jest ponadto silnie skorelowana z mówieniem. Najpierw to ona sama, uobecniając się, mówi, nade wszystko jednak sam akt rozmowy, dialogu, wpisany jest w sytuację realnej wymiany słów, ponieważ rozmawiając stajemy wobec siebie twarzą w twarz, w naoczności i bezpośredniości kontaktu. W rozmowie dochodzi do głosu autentyczność spotkania Ja - Ty. W rozmowie, w prawdziwym dialogu, Ja i Ty wychodzą niejako ku sobie, a „każdy z uczestników rzeczywiście obejmuje myślą drugiego lub drugich $\mathrm{w}$ ich bycie i sposobie bycia i zwraca się do nich $\mathrm{z}$ zamiarem ustanowienia między sobą i nim lub nimi żywej wzajemności" 20 .

Martin Buber starając się określić cechy prawdziwej rozmowy, na pierwszym miejscu wymienia afirmację drugiego w jego osobowym uobecnieniu, przyjęcie go jako partnera, potwierdzenie jego istnienia. „Niezależnie (...) od tego, w czym nie zgadzam się z drugim, uznając go za partnera prawdziwej rozmowy, mówię mu jako osobie $<$ tak $>^{\prime \prime 21}$. Następny warunek, aby powstała prawdziwa rozmowa, polega na tym, że „każdy, kto bierze w niej udział, musi włączyć samego siebie. Oznacza to, że musi być zdecydowany zawsze mówić to, co myśli na temat omawianego przedmiotu" 22 . Jak zauważa Buber: „Tam, gdzie naprawdę istnieje dialogiczne słowo, trzeba mu oddać sprawiedliwość przez otwartość" 23 . Czynnikiem bardzo ważnym jest przezwyciężenie pozoru.

Ten, kto - nawet w atmosferze prawdziwej rozmowy - kieruje się myślą o własnym oddziaływaniu jako mówcy tego, co powinno przez niego przemówić, działa jak niszczyciel. Gdy zamiast tego, co winno być powiedziane, chcę zaprezentować swoje samolubne "ja", bezpowrotnie gubię to, co miałbym do powiedzenia - niedopowiedziane wkracza to do rozmowy i niedopowiedziana staje się rozmowa. Ponieważ prawdziwa rozmowa jest sferą ontologiczną, która konstytuuje się przez autentyczność bytu, każde wtargnięcie pozoru może ją okaleczyć24.

$\mathrm{W}$ prawdziwej rozmowie, $\mathrm{W}$ autentycznym dialogu „międzyludzkie otwiera to, co kiedy indziej pozostaje zamknięte"25. Zamknięte na przykład

\footnotetext{
${ }^{20}$ M. Buber, Ja i Ty, s. 226.

${ }^{21}$ Tamże, s. 152.

22 Tamże.

23 Tamże.

24 Tamże.

25 Tamże, s. 153.
} 
są dla przedstawicieli filozofii dialogu odniesienia do rzeczy, które istnieją niejako obok, na zewnątrz. Przedmiotowa realność bycia z nimi nie przybiera postaci relacji, wzajemności.

Świat nie ma udziału w doświadczeniu. Pozwala się doświadczać, ale jego to nie dotyczy, bowiem nie dodaje doń niczego i niczego w nim nie spotyka. Świat jako doświadczenie należy do podstawowego słowa Ja - Ono. Podstawowe słowo Ja - Ty ustanawia świat relacji" 26 .

Osobliwość, można by powiedzieć swoistość i swego rodzaju ekskluzywność dialogu, zawiera się w szczególnej postawie, która charakteryzuje pozostające $\mathrm{w}$ relacji jednostki. Jest to postawa wzajemności, zaangażowania, otwartości, gotowości słuchania. Chodzi o to, aby prowadzić dialog, „rozmawiać ze sobą, a nie mimo siebie”, a co najważniejsze, jak zauważa Buber, „nie narzuca się nikomu dialogu. Opowiadanie nie jest sprawą powinności lecz możliwości" 27 . W podjętym w wolności dialogu dochodzi do uświadomienia sobie tego, że istnieje nie tylko mój punkt widzenia, wartościowania, patrzenia na rzeczywistość, jej percepcji i przeżywania. Dialogiczna relacja uprzytamnia ponadto ograniczoność jednostkowej perspektywy myślenia o sobie i świecie. Ustanawia równocześnie pewną sferę „pomiędzy”, wyznacza pewien obszar, w którym powstaje nie tyle nowa ontologiczna jakość, co pewien sposób świadomego ogarniania i rozumienia rzeczywistości. Uczestnicy dialogu komunikują sobie treści, które wypowiadane "tu i teraz", w niepowtarzalności sytuacji spotkania, żyją jakby w przestrzeni „między” Ja i TY.

Podstawowym ruchem dialogicznym jest zwrócenie się. Z pozoru jest to coś zwyczajnego i pozbawionego znaczenia: patrząc na kogoś, mówiąc do kogoś, zwracamy się przecież do niego - oczywiście fizycznie, ale w wymaganym stopniu, kierując na niego naszą uwagę, także duchowo ${ }^{28}$.

Uświadamiana $\mathrm{w}$ postawie dialogu odmienność drugiego wskazuje na jeszcze inną wartość, a mianowicie że świat międzyosobowych relacji konstytuowany jest nie tylko przez podobieństwa i tożsamości, ale także przez różnice, przez to co inne. W wyniku tego horyzonty uczestników spotkania, jak to określa Hans - Georg Gadamer, „mieszają się ze sobą”, przenikają wzajemnie i prowadzą do wytworzenia się wzajemnego rozumienia ${ }^{29}$.

${ }^{26}$ Tamże, s. 41.

27 Tamże, s. 242.

${ }^{28}$ Tamże, s. 229.

${ }^{29}$ Zob.: H.-G. Gadamer, Człowiek $i$ język, [w:] tenże, Rozum, stowo, dzieje. Szkice wybrane, przekł. M. Łukasiewicz, K. Michalski, Warszawa 1979, s. 47-56. 
Relacja z innym, której najpełniejszym wyrazem jest doświadczenie spotkania, ,jest jawna i ma kształt słowny. Możemy dawać i przyjmować Ty"30. Mówienie, dialog, odnosi się nie tyle do samej aktywności słownej, a bardziej do przyjmowania określonej postawy wobec drugiego, postawy, która uświadamiając sobie z jednej strony, że jest on kimś rzeczywiście, realnie innym, pragnie zarazem zbudować z nim wzajemność.

Człowiek chce być potwierdzony przez człowieka w swoim bycie i chce być obecny w bycie drugiego. Osoba ludzka potrzebuje potwierdzenia, ponieważ potrzebuje go człowiek jako człowiek. Nie potrzebuje go zwierzę, ponieważ nie doświadcza wątpliwości, czym jest. Inaczej człowiek: wygnany z królestwa przyrody i skazany na ryzyko kategorii samotnej, otoczonej chaosem, który narodził się wraz z nim, wygląda skrycie i lękliwie zgody na bycie, która może otrzymać tylko od drugiego człowieka31.

Chodziłoby zatem o to, aby zwracając się ku drugiemu, rzeczywiście dostrzec jego bytową osobność, niepowtarzalność, jedyność i wyjątkowość, aby uznać jego punkt widzenia i utożsamić się z nim w tym sensie, że chcemy zrozumieć jego położenie i formułowane racje.

\section{Coaching a filozofia dialogu}

Stanowiąca centrum antropologicznej refleksji filozofów dialogu relacja dialogiczna, ów dialogiczny horyzont, odgrywa również kluczową rolę w coachingu. Można by powiedzieć, że akcent postawiony na perspektywę dialogiczną, a nie na monologiczną wyłączność procesu mówienia, stanowi zasadniczy wyznacznik skuteczności podejmowanych w jego zakresie działań. Przy całej trudności zdefiniowania procesu coachingu, o czym pisałam na wstępie, relacja coachingowa zyskuje najpełniejsze oświetlenie poprzez uchwycenie jej w perspektywie spotkania i dialogu. W tym kontekście ustalenia filozofii dialogu, nurtu dialogicznego w filozoficznym myśleniu, okazują się niezwykle użyteczne. Wszystkie elementy tak zwanej pracy coachingowej, od nawiązania pełnej szacunku i zaufania relacji, poprzez fazy budowania kontaktu i przebieg procesu wzajemnego reagowania obu podmiotów, którymi są coach i klient, pozostają w wysokim stopniu odniesienia do przyjmowanych w filozofii dialogu założeń dotyczących jakości tego, co się wydarza w optyce zaistniałej diady Ja - Ty. Ukazujący się na przykład

\footnotetext{
30 Tamże, s. 41.

31 Tamże, s. 137.
} 
w filozofii dialogu, szczególnie w myśli Emmanuela Levinasa, horyzont etycznego wezwania i zobowiązania, który wypływa $\mathrm{z}$ obecności innego, będący w sensie aksjologicznym najwyższym wyrazem poczucia odpowiedzialności, wyznacza istotny rys coachingowej relacji. „Uchylanie się od odpowiedzialności to (...) blokada uniemożliwiająca wysłuchanie i zrozumienie odmiennych stanowisk oraz wyjście poza zamkniętą perspektywę"32. Zauważmy przy tym, że nie chodzi tylko o etyczność samego dialogu, jako szczególnej postaci międzyosobowego dyskursu, ale o całokształt organizowanej, modelowanej spotkaniem, wpisanym $\mathrm{w}$ niego sposobem bycia, przestrzeni między Ja i Ty. Sfera spotkania zatem, w swoim etycznym wymiarze, jest czymś znacznie szerszym od dialogu jako aktywności słownej. Odnosi się do sytuacji, w której osoby, podmioty stają wobec siebie, w której Ja znajduje się wobec Ty. Dochodzi wtedy do głosu, jak to ujmuje Józef Tischner, jakby skrzyżowanie dwóch horyzontów: aksjologicznego i agatologicznego ${ }^{33}$. Egzystencjalna perspektywa spotkania z drugim otwiera się na sferę wartości i zagadnienie Dobra i Zła.

Jednym $z$ istotnych elementów coachingowej relacji jest empatia. Autorzy analizujący empatyczne nastawienie jako narzędzie dialogu w coachingu zauważają, że nie chodzi o rozumienie jej tylko jako sympatii, akceptacji, nachylenia ku udzieleniu pomocy.

Empatia jest czystą obecnością, energią, kontaktem, otwarciem przestrzeni na pełną autentyczność, bycie z innym człowiekiem w sposób, jaki go otwiera i mu służy. Pojawia się wtedy, gdy udaje się nam zniwelować przyjęte z góry założenia, interpretacji, oceny i wyobrażenia ${ }^{34}$.

Na zdolność do empatii kładzie również akcent w analizie międzyosobowego spotkania filozofia dialogu. Pojawia się ona w charakteryzowanym przez Martina Bubera w sferze międzyludzkiej jako sui generis jako punkt szczytowy uobecnieniu. Filozof określa ją mianem realnej fantazji. Oznacza ona „że wyobrażam sobie to, co myśli, przeżywa czy czuje inny człowiek, i to nie jako oderwaną treść, lecz właśnie w rzeczywistości drugiego człowieka, to znaczy jako proces życiowy"35. Aby przybliżyć sposób Buberowskiego $\mathrm{w}$ tym względzie rozumowania posłużmy się nieco dłuższym cytatem, który eksplikuje swoistość przyjętego przez autora widzenia tej kwestii:

32 J. Marczyszyn-Berendt, E. Tyralik-Kulpa, Empatia jako narzędzie dialogu w coachingu, [w:] Coaching jako konstruktywny dialog, Warszawa 2016, s. 129.

${ }^{33}$ Zob. J. Tischner, Myślenie wedtug wartości, Kraków 2002; tegoż, Spór o istnienie człowieka, Kraków 1998.

34 J. Marczyszyn-Berendt, E. Tyralik-Kulpa, Empatia jako narzędzie dialogu, s. 133.

${ }^{35}$ M. Buber, Ja i Ty, s. 136. 
Relacja spełnia się w całkowitym uobecnieniu, kiedy nie tylko odnoszę się do drugiego człowieka jako właśnie niego, lecz w faktycznym przybliżeniu doświadczam przynależnego mu - właśnie jako jemu - doświadczenia. Dopiero wtedy staje się on dla mnie jaźnią, a usamodzielnienie jego bytu, jakie nastąpiło w pierwszym, dystansującym ruchu, okazuje się przesłanką w nowym, najbardziej ścisłym tego słowa znaczeniu: przesłanką stania-się-jaźnią-dla-mnie (...) Najbardziej wewnętrzny rozwój jaźni nie płynie bowiem, jak się chętnie dzisiaj przyjmuje, ze stosunku człowieka do siebie samego, lecz ze stosunku pomiędzy jednym i drugim, a więc ze stosunku między ludźmi, zwłaszcza zaś z dwustronności uobecnienia: z uobecnienia innej jaźni i wiedzy o uobecnieniu przez drugiego swojej własnej jaźni, a więc ze stosunku, w którym panuje dwustronna akceptacja i potwierdzenie ${ }^{36}$.

Uobecnienie, podobnie jak relacja, która zachodzi w coachingu, oznacza wyjście z egocentrycznego kręgu, stanowi rekonfigurację własnego, wewnętrznego świata tak, aby otworzył się on na drugiego w jego inności i swojskości istnienia. Wzajemna afirmacja podmiotowości pozwala na pokonanie oporu i autentyczne manifestowanie się wewnętrznego świata tak coacha jak i klienta. Zogniskowane podmiotowo samookreślanie się okazuje się nieostateczne, niejednoznaczne, może zostać poddane, $\mathrm{w}$ międzyosobowej konfrontacji, twórczemu zakwestionowaniu i zwaloryzowaniu. Stwarza to szansę na swoiste wyzwolenie, poczucie odkrycia głębszej, autentycznej sfery własnego bytu, co nie pozwala na istnienie $\mathrm{w}$ tej postaci i w tych ramach jak dotychczas.

Można by tu mówić o swoiście pojmowanej wymianie, która przyjmuje postać międzyosobowego doświadczenia. Hans - Georg Gadmer analizując istotę hermeneutycznego doświadczenia, stwierdza, że mamy w nim przede wszystkim do czynienia z mówiącą tradycją, która objawia się nam poprzez tekst, za pośrednictwem języka, który

mówi (...) sam z siebie niczym jakieś ty. Ty nie jest przedmiotem, lecz odnosi się do kogoś. (...) Ponieważ przedmiot doświadczenia sam ma tu charakter osoby, to takie doświadczenie jest fenomenem moralnym, a podobnie uzyskana na drodze doświadczenia wiedza, rozumienie innego ${ }^{37}$.

Dialektyczność relacji ja - ty w wymiarze tradycji stanowi dla autora Prawdy $i$ metody stosunek nie bezpośredni, ale refleksywny. Jest tym, co określa „świadomością historyczną”. „Świadomość historyczna - zauważa następnie - nie poszukuje w inności przeszłości przypadku pewnej ogólnej

36 Tamże, s. 137.

${ }^{37}$ H.-G. Gadamer, Prawda i metoda. Zarys hermeneutyki filozoficznej, przekł. B. Baran, Kraków 1993, s. 333-334. 
prawidłowości, lecz czegoś historycznie jednorazowego" 38 . Prowadzi to do swego rodzaju najwyższego rodzaju doświadczenia hermeneutycznego, które cechuje przede wszystkim postawa otwartości. Warto w tym miejscu przywołać in extenso słowa Gadamera, które w pewien sposób mogą oświetlać, oczywiście tylko na zasadzie per analogiam, przyjęte w coachingu założenia. Filozof ten pisze:

(...) otwartość ma rzetelny odpowiednik w doświadczeniu ty. (...) w relacjach międzyludzkich chodzi o to, by ty doświadczyć rzeczywiście jako ty, tj. nie przeoczyć jego zagadnięcia i pozwolić mu na coś odpowiedzieć. Zawiera się w tym otwartość. Ta otwartość jednak nie jest tylko otwartością na tego, od kogo chce się coś usłyszeć. Raczej ten, kto chce w ogóle coś usłyszeć, jest w zasadniczy sposób otwarty. Bez takiej otwartości na siebie nawzajem nie ma rzetelnego związku między ludźmi. Współprzynależność zawsze oznacza zarazem możność słuchania się nawzajem. (..) Otwartość na innego obejmuje więc uznanie, że muszę w sobie przyjąć coś przeciw sobie, nawet jeśli nie byłoby innego, który by to przeciw mnie uczynił ${ }^{39}$.

W tym właśnie, jak się wydaje, tkwi również zasadniczy rys, który ujawnia się w coachingu. On także zakłada i wymaga postawy otwartości, staje się interpersonalnym doświadczeniem, które wykracza poza jednostkową pewność i pozostaje $\mathrm{w}$ gotowości, w swoistym wychyleniu na głos innego, na odkrycie wzajemnej optyki i perspektywy doświadczania siebie i świata w płaszczyźnie faktów, myśli i uczuć. $\mathrm{W}$ ten sposób następuje poszukiwanie alternatywnych możliwości, samodzielne, ale i empatyczne dostrzeganie potencjalnych rozwiązań problemów.

W budowaniu coachingowej relacji i dokonujących się $\mathrm{w}$ jej ramach procesów, w podnoszeniu ich skuteczności, empatia odgrywa bardzo ważną rolę.

Połączenie głęboko transformującej mocy empatii z siłą coachingu stanowi skuteczne i głębokie narzędzie w pracy coacha. Fundamentem relacji coach - klient jest zaufanie i poczucie bezpieczeństwa (dla którego empatia ma fundamentalne znaczenie), a także świadomość, że to, co klient mówi, jest drogowskazem procesu zmiany i jest z uważnością i szacunkiem obejmowane przez coacha. Gdy klient zyskuje subiektywne poczucia bycia widzianym i bycia usłyszanym, zyskuje większy dostęp do swoich zasobów, metaforycznie wewnętrznie rozkwita. Pojawia się większa otwartość, kreatywność i gotowość, by zmierzać w kierunku transformacji ${ }^{40}$.

38 Tamże, s. 335.

39 Tamze, s. 336.

${ }^{40}$ J. Marczyszyn-Berendt, E. Tyralik-Kulpa, Empatia jako narzędzie dialogu, s. 137. 


\section{Zakończenie}

Oświetlenie coachingu z perspektywy filozofii dialogu okazuje się zabiegiem niezwykle interesującym. Wypracowana w ramach dialogicznego nurtu filozoficznego myślenia optyka oglądu "spraw ludzkich” pozwala wysnuć dalece instruktywne wnioski dla tworzenia i przebiegu międzyosobowej relacji coachingowej, dla przyjmowanego w jej ramach praktycznego postępowania. Aplikacja, szczególnie $\mathrm{w}$ planie poszerzenia świadomości i rozumienia relacji coach - klient, zasad i uwrażliwień, które przynosi filozofia dialogu okazuje się i okazać się może w jeszcze większym stopniu nadzwyczaj owocnym impulsem dla praktyki coachingu.

\section{BIBLIOGRAFIA}

Buber M., Ja i Ty. Wybór pism filozoficznych, wybrał, przełożył i wstęp napisał J. Doktór, Instytut Wydawniczy Pax, Warszawa 1992.

Coaching. Inspiracje z perspektywy nauki, praktyki i klientów, red. P. Smółka, Wydawnictwo Helion, Gliwice 2009.

Czarkowska L.D., Coaching jako konstruktywny dialog. Wprowadzenie, [w:] Coaching jako konstruktywny dialog, red. L.D. Czarkowska, Wydawnictwo Poltext, Warszawa 2016.

Gadacz T., Filozofia dialogu, [w:] tenże, Historia filozofii XX wieku. Nurty, t. 2 - Neokantyzm, filozofia egzystencji, filozofia dialogu, Wydawnictwo Znak, Kraków 2009.

Gadamer H.-G., Człowiek $i$ język, [w:] tenże, Rozum, słowo, dzieje. Szkice wybrane, przekł. M. Łukasiewicz, K. Michalski, Państwowy Instytut Wydawniczy, Warszawa 1979.

Gadamer H.-G., Prawda i metoda. Zarys hermeneutyki filozoficznej, przekł. B. Baran, Wydawnictwo Inter Esse, Kraków 1993.

Levinas E., Etyka i Nieskończony. Rozmowy z Philipp'em Nemo, przekł. B. OpolskaKokoszka, Wydawnictwo Naukowej Papieskiej Akademii Teologicznej, Kraków 1991.

Marczyszyn-Berendt J., Tyralik-Kulpa E., Empatia jako narzędzie dialogu w coachingu, [w:] Coaching jako konstruktywny dialog, red. L.D. Czarkowska, Wydawnictwo Poltext, Warszawa 2016.

Surzykiewicz J., Podstawy teoretyczne coachingu w pedagogice spotecznej pracy socjalnej: ku coachingowi spotecznemu, [w:] Coaching społeczny. W poszukiwaniu efektywnych form wsparcia osób w trudnych sytuacjach życiowych, red. J. Surzykiewicz, M. Kulesza, Wydawnictwo Difin, Warszawa 2013.

Szewczyk A., Sztuka prowadzenia dialogu w coachingu, [w:] Coaching jako konstruktywny dialog, red. L.D. Czarkowska, Wydawnictwo Poltext, Warszawa 2016.

Tischner J., Spór o istnienie człowieka, Wydawnictwo Znak, Kraków 1998.

Tischner J., Myślenie według wartości, Wydawnictwo Znak, Kraków 2002. 